\title{
Phylogeography of Rhinella spinulosa (Anura: Bufonidae) in northern Chile
}

\author{
Claudio Correa ${ }^{1}$, Luis Pastenes ${ }^{1}$, Michel Sallaberry ${ }^{2}$, Alberto Veloso ${ }^{2}$, \\ Marco A. Méndez ${ }^{1,2,3, *}$
}

\begin{abstract}
The southern part of the Altiplano of the Andes Range is characterized by a complex hydrography, due to an intense geologic activity and the effects of the Pleistocene glaciations. This has produced a high degree of diversity at the species level in some aquatic taxa (e.g., fish and amphibians), which suggests that these same processes have produced divergence at the intraspecific level in co-distributed taxa. We investigated the genetic variation in populations of the anuran Rhinella spinulosa which represent its entire distribution in the extreme north of Chile $\left(17^{\circ} 44^{\prime} \mathrm{S}-23^{\circ} 47^{\prime} \mathrm{S}\right)$. Haplotype networks of the mitochondrial control region recognized two main lineages, one of which is distributed from the northern boundary of Chile to the Salar de Alconcha and the other from the Salar de Carcote to the locality of Tilomonte. The northern lineage showed little phylogeographic structure; a few very frequent haplotypes are widely distributed. The southern lineage had greater structure, due principally to the high divergence of the populations from the eastern springs of the Salar de Atacama. Fu's Fs test and the mismatch distributions suggested that most of the populations of both lineages are in the process of demographic expansion. The spatial distribution of the genetic variability was correlated with the hydrography and the paleoclimatological data available for the region, which suggested that geographic expansions followed by periods of contraction of population ranges, together with sporadic floods may explain the observed phylogeographic patterns.
\end{abstract}

Keywords: anuran, Chilean Altiplano, mtDNA, phylogeographic structure.

\section{Introduction}

The Altiplano or Puna is an extensive highaltitude tableland located in the central Andes range, which includes parts of Peru, Bolivia, Chile and Argentina. This region has been affected by profound geological and climatic changes produced by the lifting of the Andes, volcanism and Pleistocene glaciations (Trumbull et al., 2006; Strecker et al., 2007), whose combined influence has determined the biogeographic and diversification patterns of its flora and fauna (Veloso et al., 1982; Arroyo et al., 1988; Ezcurra, 2002; Palma et al., 2002; Koscinski et al., 2008). In a wider biogeo-

1 - Laboratorio de Genética y Evolución, Departamento de Ciencias Ecológicas, Facultad de Ciencias, Universidad de Chile, P.O. Box 653, Santiago, Chile

2 - Laboratorio de Vertebrados, Departamento de Ciencias Ecológicas, Facultad de Ciencias, Universidad de Chile, P.O. Box 653, Santiago, Chile

3 - Center for Advanced Studies in Ecology \& Biodiversity and Departamento de Ecología, Pontificia Universidad Católica de Chile, P.O. Box 6513677, Santiago, Chile

*Corresponding author; e-mail: mmendez@inta.cl graphic context, this region is considered to form part of an Andean transition zone where tropical and austral elements have mixed, which would also have contributed to the diversification of its flora and fauna (Morrone, 2004).

In Chile, the Altiplano occupies a narrow strip in the northeast corner of the country from approximately $17^{\circ} 30^{\prime} \mathrm{S}$ to $24^{\circ} \mathrm{S}$, limited on the west by the eastern Andes Range. With a mean altitude of $4200 \mathrm{~m}$, this region is characterized by a dry, cold climate which has produced mainly steppe vegetation (Veloso and Arroyo, 1982). The scarce precipitation in this zone comes from the tropical area to the East, but does not reach beyond the western Andes slopes to the Atacama Desert (Garreaud et al., 2003). Hydrographically, the majority of the northeast corner of Chile is occupied by endorheic drainage systems, which are limited to the west by endorheic or arheic basins which originate in the western slopes of the Andes and enter the Atacama Desert (e.g., Pampa del Tamarugal; fig. 1). The only exorheic systems of this zone are the Lluta and Azapa rivers, located in the 


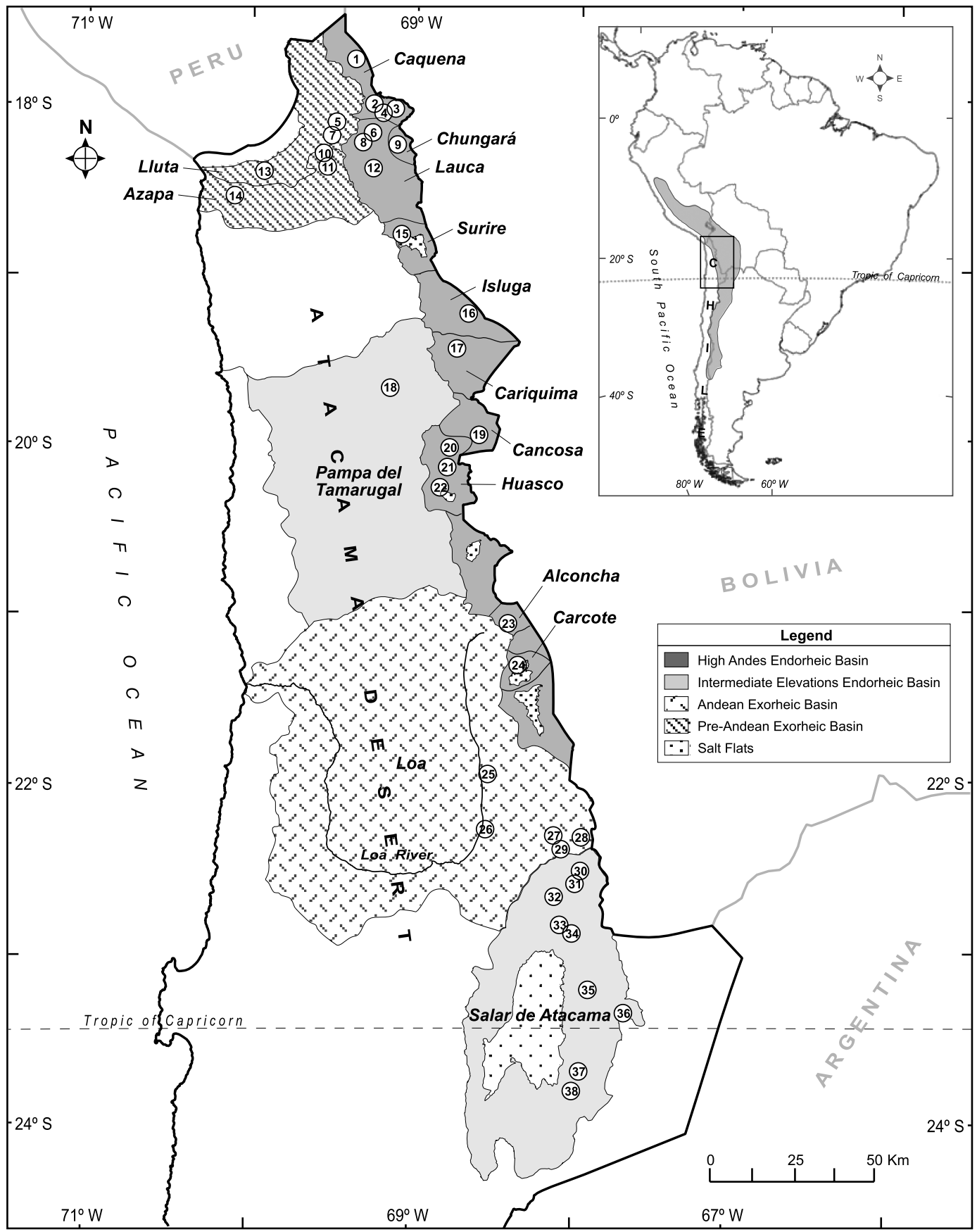

Figure 1. Map of northern Chile showing the localities (numbered circles) of Rhinella spinulosa included in this study (table 1 specifies the number of each locality). The names and limits of the hydrographic basins within Chile where the species is found are shown (thin solid lines). The different types of drainage basins are indicated with different gray tones and patterns. The map in the upper right shows the geographic distribution of $R$. spinulosa in South America (gray area).

extreme north of the country, and the Loa River (Niemeyer and Cereceda, 1984; fig. 1). Associated with the complex hydrography of this part of Chile, a high richness has been described at the species level for some aquatic taxa, such as the amphibians of the genus Telmatobius 
Table 1. Number of specimens utilized (n) and geographic data of the localities of Rhinella spinulosa included in this study. The first column indicates the number $(\mathrm{N})$ which represents each of the localities in the map of fig. 1. The last column indicates the haplotypes found in each population, numbered according to the network (fig. 2).

\begin{tabular}{|c|c|c|c|c|c|c|c|}
\hline $\mathrm{N}$ & Locality & $\mathrm{n}$ & Basin name & Latitude (S) & Longitude (W) & Altitude (m) & Haplotypes \\
\hline 1 & Umaqui & 3 & Caquena & $17^{\circ} 44^{\prime} 07^{\prime \prime}$ & $69^{\circ} 23^{\prime} 13^{\prime \prime}$ & 4132 & 1,2 \\
\hline 2 & Vioco & 4 & Caquena & $18^{\circ} 02^{\prime} 31^{\prime \prime}$ & $69^{\circ} 16^{\prime} 45^{\prime \prime}$ & 4383 & 1,3 \\
\hline 3 & Caquena & 4 & Caquena & $18^{\circ} 03^{\prime} 33^{\prime \prime}$ & $69^{\circ} 12^{\prime} 16^{\prime \prime}$ & 4398 & $1,4-6$ \\
\hline 4 & Colpa & 1 & Caquena & $18^{\circ} 03^{\prime} 34^{\prime \prime}$ & $69^{\circ} 13^{\prime} 59^{\prime \prime}$ & 4356 & 7 \\
\hline 5 & Pacollo & 6 & Lluta & $18^{\circ} 10^{\prime} 46^{\prime \prime}$ & $69^{\circ} 31^{\prime} 10^{\prime \prime}$ & 4090 & $1,8-9$ \\
\hline 6 & Lauca & 2 & Lauca & $18^{\circ} 11^{\prime} 39^{\prime \prime}$ & $69^{\circ} 16^{\prime} 25^{\prime \prime}$ & 4395 & 1 \\
\hline 7 & Putre & 8 & Lluta & $18^{\circ} 11^{\prime} 47^{\prime \prime}$ & $69^{\circ} 33^{\prime} 35^{\prime \prime}$ & 3507 & $9-13$ \\
\hline 8 & Parinacota & 14 & Lauca & $18^{\circ} 12^{\prime} 52^{\prime \prime}$ & $69^{\circ} 18^{\prime} 05^{\prime \prime}$ & 4399 & $1,9,14-17$ \\
\hline 9 & Chungará & 5 & Chungará & $18^{\circ} 13^{\prime} 57^{\prime \prime}$ & $69^{\circ} 10^{\prime} 53^{\prime \prime}$ & 4583 & $1,9,18-19$ \\
\hline 10 & Socoroma & 5 & San José de Azapa & $18^{\circ} 15^{\prime} 48^{\prime \prime}$ & $69^{\circ} 36^{\prime} 09^{\prime \prime}$ & 3058 & $9,12-13,20$ \\
\hline 11 & Zapahuira & 9 & San José de Azapa & $18^{\circ} 19^{\prime} 50^{\prime \prime}$ & $69^{\circ} 35^{\prime} 30^{\prime \prime}$ & 3320 & $8,11-13,20$ \\
\hline 12 & Chivatambo & 4 & Lauca & $18^{\circ} 21^{\prime} 41^{\prime \prime}$ & $69^{\circ} 16^{\prime} 38^{\prime \prime}$ & 4329 & 1,18 \\
\hline 13 & Lluta & 2 & Lluta & $18^{\circ} 23^{\prime} 46^{\prime \prime}$ & $69^{\circ} 58^{\prime} 23^{\prime \prime}$ & 836 & 12 \\
\hline 14 & Azapa & 3 & San José de Azapa & $18^{\circ} 31^{\prime} 14^{\prime \prime}$ & $70^{\circ} 10^{\prime} 30^{\prime \prime}$ & 287 & $12,21-22$ \\
\hline 15 & Surire & 6 & Surire & $18^{\circ} 51^{\prime} 01^{\prime \prime}$ & $69^{\circ} 08^{\prime} 25^{\prime \prime}$ & 4081 & $1,14,23$ \\
\hline 16 & Isluga & 3 & Isluga & $19^{\circ} 15^{\prime} 10^{\prime \prime}$ & $68^{\circ} 42^{\prime} 16^{\prime \prime}$ & 3776 & 1,14 \\
\hline 17 & Quebe & 16 & Cariquima & $19^{\circ} 27^{\prime} 18^{\prime \prime}$ & $68^{\circ} 48^{\prime} 34^{\prime \prime}$ & 3958 & $1,23-26$ \\
\hline 18 & Chusmisa & 8 & Pampa del Tamarugal & $19^{\circ} 40^{\prime} 45^{\prime \prime}$ & $69^{\circ} 10^{\prime} 53^{\prime \prime}$ & 3213 & $21-22$ \\
\hline 19 & Cancosa & 6 & Cancosa & $19^{\circ} 57^{\prime} 24^{\prime \prime}$ & $68^{\circ} 41^{\prime} 59^{\prime \prime}$ & 4007 & $1,7,23$ \\
\hline 20 & El Piga & 1 & Huasco & $20^{\circ} 01^{\prime} 57^{\prime \prime}$ & $68^{\circ} 49^{\prime} 16^{\prime \prime}$ & 3944 & 23 \\
\hline 21 & Collacagua & 5 & Huasco & $20^{\circ} 07^{\prime} 50^{\prime \prime}$ & $68^{\circ} 50^{\prime} 31^{\prime \prime}$ & 3859 & 1,23 \\
\hline 22 & Huasco & 11 & Huasco & $20^{\circ} 16^{\prime} 45^{\prime \prime}$ & $68^{\circ} 53^{\prime} 17^{\prime \prime}$ & 3805 & 1,23 \\
\hline 23 & Alconcha & 2 & Alconcha & $21^{\circ} 03^{\prime} 39^{\prime \prime}$ & $68^{\circ} 29^{\prime} 18^{\prime \prime}$ & 4100 & 23 \\
\hline 24 & Carcote & 7 & Carcote & $21^{\circ} 16^{\prime} 46^{\prime \prime}$ & $68^{\circ} 19^{\prime} 21^{\prime \prime}$ & 3688 & 27 \\
\hline 25 & Loa & 5 & Loa & $21^{\circ} 56^{\prime} 50^{\prime \prime}$ & $68^{\circ} 36^{\prime} 37^{\prime \prime}$ & 3053 & 28 \\
\hline 26 & Lasana & 1 & Loa & $22^{\circ} 16^{\prime} 22^{\prime \prime}$ & $68^{\circ} 37^{\prime} 49^{\prime \prime}$ & 2610 & 28 \\
\hline 27 & Caspana & 6 & Loa & $22^{\circ} 20^{\prime} 03^{\prime \prime}$ & $68^{\circ} 12^{\prime} 30^{\prime \prime}$ & 3245 & $28-29$ \\
\hline 28 & El Tatio & 19 & Loa & $22^{\circ} 20^{\prime} 10^{\prime \prime}$ & $68^{\circ} 00^{\prime} 59^{\prime \prime}$ & 4264 & $28,30-35$ \\
\hline 29 & Chita & 10 & Loa & $22^{\circ} 24^{\prime} 52^{\prime \prime}$ & $68^{\circ} 10^{\prime} 21^{\prime \prime}$ & 3741 & 28 \\
\hline 30 & Vado Río Putana & 7 & Salar de Atacama & $22^{\circ} 31^{\prime} 42^{\prime \prime}$ & $68^{\circ} 02^{\prime} 35^{\prime \prime}$ & 4286 & $28-29,31,36-37$ \\
\hline 31 & Machuca & 6 & Salar de Atacama & $22^{\circ} 35^{\prime} 50^{\prime \prime}$ & $68^{\circ} 03^{\prime} 52^{\prime \prime}$ & 3979 & $28,37-38$ \\
\hline 32 & Río Grande & 6 & Salar de Atacama & $22^{\circ} 39^{\prime} 56^{\prime \prime}$ & $68^{\circ} 13^{\prime} 38^{\prime \prime}$ & 3045 & $28-29$ \\
\hline 33 & Katarpe & 10 & Salar de Atacama & $22^{\circ} 50^{\prime} 02^{\prime \prime}$ & $68^{\circ} 11^{\prime} 55^{\prime \prime}$ & 2460 & $28-29,37$ \\
\hline 34 & Vilama & 14 & Salar de Atacama & $22^{\circ} 51^{\prime} 49^{\prime \prime}$ & $68^{\circ} 10^{\prime} 50^{\prime \prime}$ & 2579 & $28-29,37$ \\
\hline 35 & Quebrada de Jere & 23 & Salar de Atacama & $23^{\circ} 11^{\prime} 08^{\prime \prime}$ & $67^{\circ} 59^{\prime} 27^{\prime \prime}$ & 2513 & $29,39-44$ \\
\hline 36 & Tumbre & 5 & Salar de Atacama & $23^{\circ} 19^{\prime} 13^{\prime \prime}$ & $67^{\circ} 47^{\prime} 34^{\prime \prime}$ & 3761 & 29 \\
\hline 37 & Peine & 9 & Salar de Atacama & $23^{\circ} 41^{\prime} 00^{\prime \prime}$ & $68^{\circ} 03^{\prime} 31^{\prime \prime}$ & 2440 & 45 \\
\hline 38 & Tilomonte & 17 & Salar de Atacama & $23^{\circ} 47^{\prime} 24^{\prime \prime}$ & $68^{\circ} 06^{\prime} 34^{\prime \prime}$ & 2365 & $46-48$ \\
\hline
\end{tabular}

(Veloso et al., 1982; Formas et al., 2005) and the fishes of the genus Orestias (Dyer, 2000; Lüssen et al., 2003).

There have been few studies that have investigated patterns of genetic differentiation at the specific or population level in the extreme north of Chile (Lüssen et al., 2003; Méndez et al., 2004; Palma et al., 2005). Lüssen et al. (2003) studied the phylogenetic relationships of the species of the genus Orestias in this area, suggesting a diversification of this group in the late Pleistocene. Palma et al. (2005), in a study of the phylogenetic relationships of species of sigmodontine rodents of the Chilean Altiplano and areas around the Atacama desert, found a high degree of phylogeographic differentiation between some of these species, suggesting a peripatric speciation model for this group of rodents. At the population level, Méndez et al. (2004) compared morphological and genetic variation among populations of the amphibian Rhinella spinulosa (as Bufo spinulo- 
sus $)$ in the north $\left(18^{\circ} 12^{\prime} \mathrm{S}-18^{\circ} 31^{\prime} \mathrm{S}\right.$ and $22^{\circ} 20^{\prime} \mathrm{S}$ $\left.23^{\circ} 11^{\prime} \mathrm{S}\right)$ and central $\left(32^{\circ} 51^{\prime} \mathrm{S}-33^{\circ} 21^{\prime} \mathrm{S}\right)$ zones of Chile. They found a positive correlation between morphological and genetic distances (obtained with nuclear RAPD markers) and a high level of genetic divergence between the two groups of populations of $R$. spinulosa from northern Chile, which was as great as between one of them and populations from central Chile. This last result suggested the presence of two highly divergent lineages in the north of Chile, but since the sampling only included two groups of populations separated by more than $450 \mathrm{~km}$, it was not possible to obtain more precise information on the geographic distribution of those lineages.

$R$. spinulosa is widely distributed in the central and southern Andes (fig. 1) and is found throughout the Chilean Altiplano and contiguous zones between 2000 and $4600 \mathrm{~m}$. Only in the extreme north of Chile, at around $18^{\circ} 25^{\prime} \mathrm{S}$, populations have been found below $1000 \mathrm{~m}$ (Veloso et al., 1982; fig. 1). This is a polytypic species which includes several morphologically differentiated populations whose taxonomic status still is not clear (Cei, 1972). However, there still is no comprehensive phylogeographic study that clarifies the relationships among its populations and their levels of genetic divergence. The objective of the present study was to establish the distribution limits and patterns of genetic variation of the lineages detected by Méndez et al. (2004) in northern Chile by analyzing DNA sequences from the mitochondrial control region in an extensive sampling that included all the known distribution range in this region. The intra- and inter-population genetic variability and levels of phylogeographic structure of the main intra-specific lineages were examined in relation to the complex paleoclimatic and hydrogeographic history of this area of Chile to identify the historical and current processes that may explain this differentiation.

\section{Materials and methods}

We included a total of 273 specimens of Rhinella spinulosa from 38 Chilean localities located between $17^{\circ} 44^{\prime} 07^{\prime \prime} \mathrm{S}$ and $23^{\circ} 47^{\prime} 24^{\prime \prime} \mathrm{S}$ and between $67^{\circ} 47^{\prime} 34^{\prime \prime} \mathrm{W}$ and $70^{\circ} 10^{\prime} 30^{\prime \prime} \mathrm{W}$ (table 1, fig. 1). The samples included adults, juveniles, post-metamorphics and larvae; specimens are deposited in the Herpetological Collection of the Departamento de Biología Celular y Genética de la Universidad de Chile (DBGUCH). All individuals used in this study were treated in accordance with procedures approved by the Ethics Committee of the Universidad de Chile and the Chilean Comisión Nacional de Investigación Científica (CONICYT), which are based on the recommendations of the National Research Council (USA) (1996).

Total DNA was isolated from samples of toe, liver or muscle, using a modification of the salt extraction method of Jowett (1986). A fragment of the control region of mitochondrial DNA was amplified using primers CytbA-L (5'GAATYGGRGGWCAACCAGTAGAAGACCC- $\left.3^{\prime}\right)$ and ControlP-H (5'-GTCCATAGATTCASTTCCGTCAG-3') reported by Goebel et al. (1999). The reaction mixtures included $3 \mathrm{mM}$ of $\mathrm{MgCl}_{2}, 0.16 \mathrm{mM}$ of each dNTP, $0.26 \mu \mathrm{M}$ of each primer, $1.5 \mathrm{U}$ of Taq polymerase (Invitrogen, Carlsbad, CA) and 50-100 ng of total DNA. The thermal profile for PCR was: $94^{\circ} \mathrm{C}$ for $2 \mathrm{~min}$, followed by 36 cycles of $94^{\circ} \mathrm{C}$ for $30 \mathrm{~s}, 56^{\circ} \mathrm{C}$ for $45 \mathrm{~s}$ and $72^{\circ} \mathrm{C}$ for $90 \mathrm{~s}$, with a final extension at $72^{\circ} \mathrm{C}$ for $10 \mathrm{~min}$. The PCR products were sequenced in both directions in an ABI3730XL automatic sequencer (Applied Biosystems).

The DNA sequences of each individual were edited using the program BioEdit v.7.0.7.0 (Hall, 1999). Multiple alignment of the edited sequences was performed with the ClustalX v.1.81 program (Thompson et al., 1997) using the default parameters; alignments were then inspected visually. Haplotypes were obtained using the DnaSP v.4.50.3 program (Rozas et al., 2003).

The genetic variation patterns of the populations of $R$. spinulosa were studied using a combination of phylogeographic tools:

1. Haplotype networks were obtained using the medianjoining network method (Bandelt et al., 1999), with the Network v.4.5.1.0 program (http://www.fluxusengineering.com/sharenet.htm). The haplotypes for this analysis were generated including the sites with indels.

2. The phylogeographic structure of the populations was also investigated using spatial molecular analysis of variance using the SAMOVA v.1.0 program (Dupanloup et al., 2002). This program finds groups of contiguous populations that maximize the betweengroups variance.

3. Two types of approximations were used to obtain information on the demographic history of the populations, using the groups recognized in the haplotype networks as units. The neutrality of the sequences was evaluated with Tajima's $D$ statistic, and additionally the Fu's $F s$ test, to examinate whether the populations are in a process of population expansion. Finally, we obtained the mismatch distribution 
of the groups of sequences, comparing them with a model of population expansion (Rogers and Harpending, 1992). All these analyses were performed with the DnaSP v.4.50.3 program, excluding the sites with indels.

4. We calculated the following diversity indices for the main groups defined in the haplotype network and for populations with sample size of $\mathrm{N} \geqslant 5$ : number of haplotypes, haplotype diversity and nucleotide diversity, using the program DnaSP v.4.50.3. We also calculated the uncorrected p-distances within and between the main groups defined by the haplotype network using the program MEGA4 (Tamura et al., 2007). The standard errors of the distances were estimated using bootstrap (100 pseudoreplicates).

\section{Results}

\section{Sequence analysis}

A total of 863 nucleotide sites were obtained as the final result of the multiple alignment, of which 70 were polymorphic and seven had indels. From the 273 sequences analyzed, 48 haplotypes were recovered when the indel sites were considered. The sequences were deposited in GenBank, with accession numbers AY663444-AY663517 and FJ643078FJ643276.

\section{Phylogeographic analyses}

The network analysis showed two principal groups of highly divergent haplotypes (fig. 2): the northern lineage, composed of haplotypes 1 to 26 , corresponding to the populations from the endorheic systems of the high Andes, preAndean exorheic systems and the Pampa del Tamarugal $\left(17^{\circ} 44^{\prime} \mathrm{S}-21^{\circ} 04^{\prime} \mathrm{S}\right)$, and the southern lineage, composed of haplotypes 27 to 49 , from the drainage basins of Carcote, the Loa River and the Salar de Atacama $\left(21^{\circ} 17^{\prime} \mathrm{S}-23^{\circ} 47^{\prime} \mathrm{S}\right)$. The haplotype network of the northern lineage showed a low level of phylogeographic structure (i.e., the majority of the haplotypes are separated by few mutational steps), where the most frequent haplotypes have a very wide geographic distribution (table 1). By contrast, in the network of the southern lineage a high level of phylogeographic structure was found, due to the high divergence beetwen two groups of haplotypes (or haplogroups): (1) Populations from the drainage systems of Carcote, the Loa River and the northeast of the Salar de Atacama; (2) Quebrada de Jere, Peine and Tilomonte. The first haplogroup has the widest geographic distribution, reaching the locality of Tumbre $\left(23^{\circ} 19^{\prime} 13^{\prime \prime} \mathrm{S}\right)$, which is in the Salar de Atacama drainage system southeast of Quebrada de Jere (haplogroup 2). A singular aspect of the southern lineage is the overlapping of haplogroups 1 and 2 (fig. 2), since haplotype 29, one of the most frequent and widely distributed of haplogroup 1, is present in Quebrada de Jere (11 sequences) together with haplotypes restricted to this locality (12 sequences).

The SAMOVA analysis revealed a greater phylogeographic structure (i.e., the variance component among groups was greater than within groups or within populations) for the southern lineage than for the northern lineage (table 2). The four groups of populations found for the northern lineage were: (1) $\mathrm{Pa}$ collo, Putre, Socoroma, Zapahuira and Lluta, located between 800 and $3800 \mathrm{~m}$; (2) Chusmisa (3213 m) and Azapa (287 m); (3) Vioco, Caquena, Colpa, Lauca, Parinacota, Chungará, Chivatambo, Surire, Isluga, Quebe, Cancosa, El Piga, Collacagua, Huasco and Alconcha, all over $3800 \mathrm{~m}$; and (4) Umaqui (4132 m), which is the northernmost population included in this study. Five groups were found for the southern lineage: (1) Carcote (3688 m); (2) Loa, Lasana, Caspana, El Tatio, Chita, Vado Río Putana, Machuca, Río Grande, Katarpe and Vilama, located in the drainage system of the Loa River and in the springs of the northeast of the drainage basin of the Salar de Atacama (2579$4286 \mathrm{~m}$ ). The other three groups are populations from the currently isolated eastern springs of the Salar de Atacama basin: (3) Quebrada de Jere $(2513 \mathrm{~m})$; (4) Peine $(2440 \mathrm{~m})$; and (5) Tilomonte $(2365 \mathrm{~m})$. 


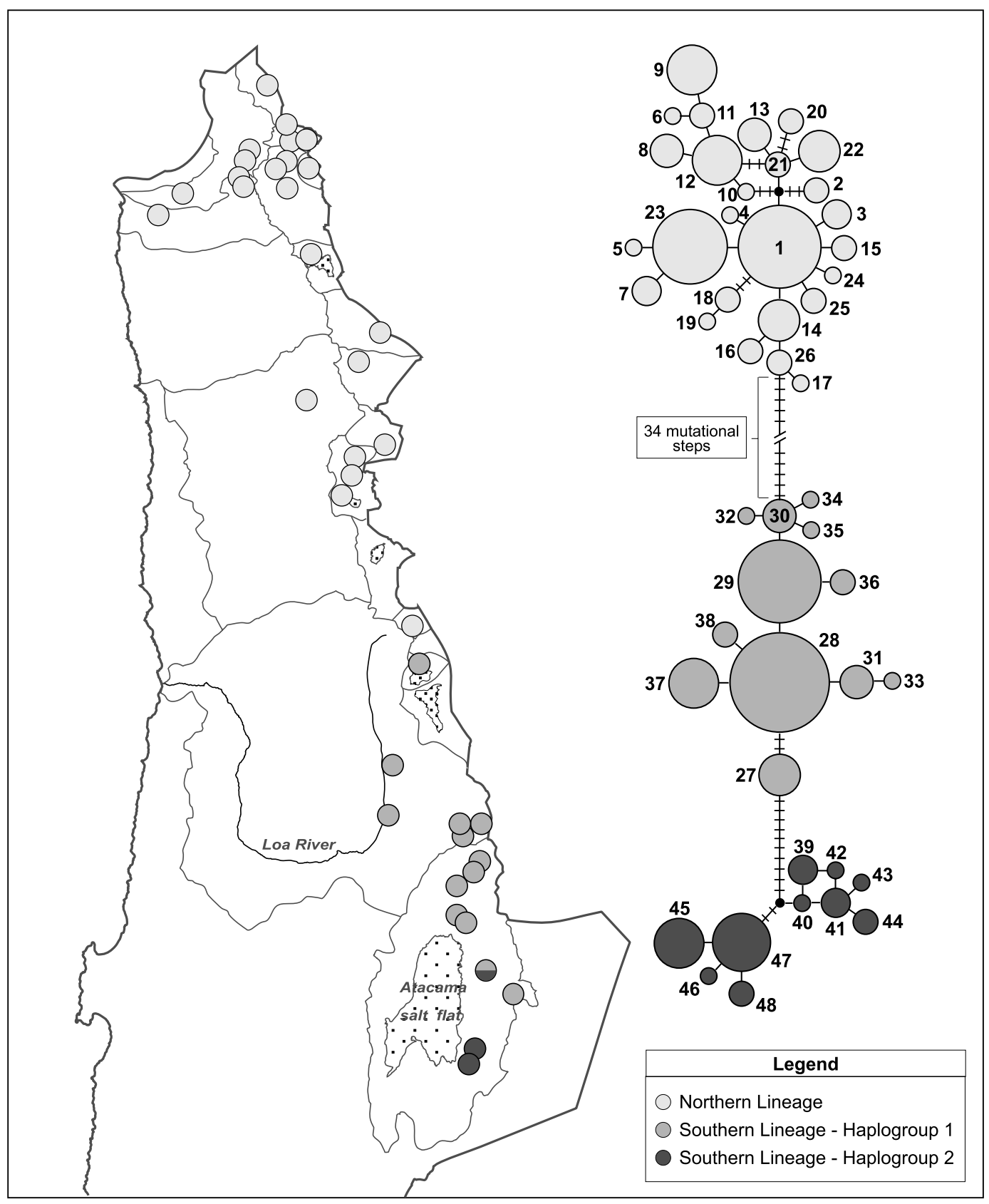

Figure 2. Haplotype network constructed using the median-joining method for the 48 mitochondrial haplotypes found in 273 individuals of Rhinella spinulosa from northern Chile. Haplotypes 1 to 26 are from the northern lineage; haplotypes 27 to 28 are from the southern lineage. The different degrees of shading of the localities (circles in the map) indicate the three main haplotype groups observed in the network. The size of circles in the network is proportional to the sampling frequency of haplotypes. The short transverse lines on the branches indicate the inferred mutational steps between the haplotypes (omitted when there was only one mutational step).

\section{Demographic analyses}

The definition of the groups of sequences to use in the tests of Tajima's $D$ and Fu's $F s$ and the analysis of mismatch distributions was based on the groupings detected in the haplotype network and SAMOVA. For the northern lineage 
we defined two groups, taking into account the principal divisions found in SAMOVA: (1) the haplotypes of populations mainly from over $3800 \mathrm{~m}$ (81 sequences) and (2) the haplotypes of populations mainly from below $3800 \mathrm{~m}$ (45 sequences). Two sequences from the population of Umaqui (haplotype 2) were excluded from this analysis because they showed the same degree of divergence with respect to the two groups just mentioned. Three groups were defined for the southern lineage: (1) haplotypes present in the drainage systems of Carcote, the Loa River and the springs from the northern part of the Salar de Atacama (107 sequences); (2) Quebrada de Jere (12 sequences); and (3) Peine and Tilomonte (26 sequences). Excluding the sites with indels, the analyses were performed on 858 sites for the groups of the northern lineage and 859 for the southern lineage.

Tajima's $D$ indicated that all the groups of sequences mentioned above conform to a model of neutral evolution $(P>0.1)$. Although the

Table 2. Percentages of variance for the components (sources of variation) of the spatial analysis of molecular variance (SAMOVA) for the two principal lineages of Rhinella spinulosa recognized in the haplotype network.

\begin{tabular}{lcc}
\hline Source of variation & $\begin{array}{c}\text { Northern lineage } \\
\text { (four groups) }\end{array}$ & $\begin{array}{c}\text { Southern linage } \\
\text { (five groups) }\end{array}$ \\
\hline Among groups & $50.09^{*}$ & $78.55^{*}$ \\
Among populations & $7.28^{*}$ & $0.99^{*}$ \\
within groups & & \\
Within populations & $42.64^{*}$ & $20.45^{*}$ \\
\hline
\end{tabular}

* $(P<0.05)$. five groups showed negative values for Fu's $F s$ test, these were only significant for Group 1 of the northern lineage and Group 1 of the southern lineage (table 3). The mismatch distribution showed a unimodal pattern that fits a model of expansion for the five groups of sequences defined above, suggesting that the corresponding populations are in a process of population expansion (table 3). A detail of uncorrected pdistances within and among lineages and haplogroups is shown in table 4. Additionally, diversity indeces for lineages, haplogroups and populations are specified in table 5 .

\section{Discussion}

The mitochondrial evidence obtained in this study shows that the Chilean Altiplano and adjacent areas to the west, between $17^{\circ} 44^{\prime} \mathrm{S}$ and $23^{\circ} 47^{\prime} \mathrm{S}$, are inhabited by two highly divergent lineages of Rhinella spinulosa (fig. 2; table 4). The limit between the two lineages is between the drainage systems of the Salar de Alconcha and the Salar de Carcote, approximately between $21^{\circ} 05^{\prime} \mathrm{S}$ and $21^{\circ} 15^{\prime} \mathrm{S}$. Méndez et al. (2004) analyzed the genetic variation of this species in northern and central Chile with nuclear RAPD markers, suggesting the existence of two lineages in the north. Given that Méndez et al. (2004) included only a few populations from the north, it was not possible to discount the possibility that genetically interme-

Table 3. Results of Tajima's $D[P]$ and Fu's $F s[P]$ tests and the mismatch distributions for the groups of haplotypes of Rhinella spinulosa recognized in this study. $\mathrm{Pi}=$ nucleotide diversity. Theta/site $=$ theta per site, calculated using Eta (total number of mutations); Unimodal = unimodal distribution; Expansion $=$ model of population expansion.

\begin{tabular}{lccrrr}
\hline & Pi & Theta/site & Tajima's $D$ & Fu's $F s$ & Mismatch distribution \\
\hline $\begin{array}{l}\text { Northern lineage } \\
\text { Group 1 }\end{array}$ & 0.00126 & 0.00329 & $-1.73611[\mathrm{NS}]$ & $-9.139[0.000]$ & Unimodal, Expansion \\
$\quad$ Group 2 & 0.00312 & 0.00267 & $0.49961[\mathrm{NS}]$ & $-0.967[\mathrm{NS}]$ & Unimodal, Expansion \\
Southern lineage & & & & & \\
$\quad$ Group 1 & 0.00118 & 0.00178 & $-0.80379[\mathrm{NS}]$ & $-2.823[0.034]$ & Unimodal, Expansion \\
$\quad$ Group 2 & 0.00158 & 0.00115 & $1.22248[\mathrm{NS}]$ & $-1.132[\mathrm{NS}]$ & Unimodal, Expansion \\
Group 3 & 0.00081 & 0.00091 & $-0.28338[\mathrm{NS}]$ & $-0.583[\mathrm{NS}]$ & Unimodal, Expansion \\
\hline
\end{tabular}

$[\mathrm{NS}]=$ not significant $(P>0.05)$ 
Table 4. Uncorrected p-distances between (below the diagonal) and within (on the diagonal) the main lineages distinguished in the haplotype network. The values are mean \pm standard error. The number of sequences used for each group is indicated (n). The sequences from Quebrada de Jere, which include haplotypes of the two haplogroups of the southern lineage, were considered in their respective haplogroups (see details in Results).

\begin{tabular}{lrccc}
\hline Lineage & $\mathrm{n}$ & Northern & Southern (haplogroup 1) & Southern (haplogroup 2) \\
\hline Northern & 128 & $0.00347 \pm 0.00109$ & & \\
Southern (haplogroup 1) & 107 & $0.0398 \pm 0.0066$ & $0.00118 \pm 0.00061$ & $0.00290 \pm 0.00107$ \\
Southern (haplogroup 2) & 38 & $0.0414 \pm 0.0069$ & $0.0147 \pm 0.0037$ & \\
\hline
\end{tabular}

Table 5. Number of haplotypes, haplotype diversity and nucleotide diversity for the main lineages distinguished in the haplotype network and populations with a sample size of 5 or more. The diversity values are mean \pm standard deviation (sd). Also indicated are the number of sequences used for each group or population, the total number of nucleotide sites occupied and the number of polymorphic sites; the last two include the sites with indels.

\begin{tabular}{|c|c|c|c|c|c|c|}
\hline Group or population & $\begin{array}{c}\mathrm{n}^{\circ} \\
\text { sequences }\end{array}$ & $\begin{array}{c}\mathrm{n}^{\circ} \\
\text { haplotypes }\end{array}$ & $\begin{array}{c}\mathrm{n}^{\circ} \\
\text { sites }\end{array}$ & $\begin{array}{c}\text { Polymorphic } \\
\text { sites }\end{array}$ & $\begin{array}{c}\text { Haplotype } \\
\text { diversity } \pm \text { sd }\end{array}$ & $\begin{array}{c}\text { Nucleotide } \\
\text { diversity } \pm \mathrm{sd}\end{array}$ \\
\hline Total & 273 & 48 & 863 & 70 & $0.938 \pm 0.006$ & $0.0252 \pm 0.0123$ \\
\hline Northern lineage & 128 & 26 & 859 & 24 & $0.892 \pm 0.016$ & $0.0037 \pm 0.0021$ \\
\hline Pacollo & 6 & 3 & 858 & 7 & $0.800 \pm 0.122$ & $0.0044 \pm 0.0029$ \\
\hline Putre & 8 & 5 & 858 & 6 & $0.857 \pm 0.108$ & $0.0024 \pm 0.0017$ \\
\hline Parinacota & 14 & 6 & 859 & 10 & $0.846 \pm 0.061$ & $0.0044 \pm 0.0027$ \\
\hline Chungará & 5 & 4 & 858 & 9 & $0.900 \pm 0.161$ & $0.0047 \pm 0.0033$ \\
\hline Socoroma & 5 & 4 & 858 & 6 & $0.900 \pm 0.161$ & $0.0037 \pm 0.0027$ \\
\hline Zapahuira & 9 & 5 & 858 & 7 & $0.861 \pm 0.087$ & $0.0030 \pm 0.0020$ \\
\hline Surire & 6 & 3 & 859 & 2 & $0.600 \pm 0.215$ & $0.0010 \pm 0.0009$ \\
\hline Quebe & 16 & 5 & 859 & 5 & $0.608 \pm 0.130$ & $0.0011 \pm 0.0009$ \\
\hline Chusmisa & 8 & 2 & 858 & 1 & $0.250 \pm 0.180$ & $0.0003 \pm 0.0004$ \\
\hline Cancosa & 6 & 3 & 858 & 2 & $0.733 \pm 0.155$ & $0.0010 \pm 0.0009$ \\
\hline Collacagua & 5 & 2 & 858 & 1 & $0.600 \pm 0.175$ & $0.0007 \pm 0.0008$ \\
\hline Huasco & 11 & 2 & 858 & 1 & $0.327 \pm 0.153$ & $0.0004 \pm 0.0005$ \\
\hline Southern lineage & 145 & 22 & 863 & 28 & $0.863 \pm 0.017$ & $0.0077 \pm 0.0040$ \\
\hline Haplogroup 1 & 107 & 12 & 862 & 11 & $0.771 \pm 0.026$ & $0.0015 \pm 0.0011$ \\
\hline Carcote & 7 & 1 & 861 & 0 & $0.000 \pm 0.000$ & $0.0000 \pm 0.0000$ \\
\hline Loa & 5 & 1 & 862 & 0 & $0.000 \pm 0.000$ & $0.0000 \pm 0.0000$ \\
\hline Caspana & 6 & 2 & 862 & 1 & $0.533 \pm 0.172$ & $0.0006 \pm 0.0007$ \\
\hline Tatio & 19 & 7 & 862 & 6 & $0.819 \pm 0.054$ & $0.0022 \pm 0.0015$ \\
\hline Chita & 10 & 1 & 862 & 0 & $0.000 \pm 0.000$ & $0.0000 \pm 0.0000$ \\
\hline Vado Río Putana & 7 & 5 & 862 & 4 & $0.905 \pm 0.103$ & $0.0021 \pm 0.0016$ \\
\hline Machuca & 6 & 3 & 862 & 2 & $0.733 \pm 0.155$ & $0.0010 \pm 0.0009$ \\
\hline Río Grande & 6 & 2 & 862 & 1 & $0.533 \pm 0.172$ & $0.0006 \pm 0.0007$ \\
\hline Katarpe & 10 & 3 & 862 & 2 & $0.733 \pm 0.076$ & $0.0012 \pm 0.0010$ \\
\hline Vilama & 14 & 3 & 862 & 2 & $0.626 \pm 0.105$ & $0.0010 \pm 0.0009$ \\
\hline Tumbre & 5 & 1 & 862 & 0 & $0.000 \pm 0.000$ & $0.0000 \pm 0.0000$ \\
\hline Haplogroup 2 & 38 & 10 & 863 & 10 & $0.804 \pm 0.046$ & $0.0030 \pm 0.0018$ \\
\hline Quebrada de Jere (total) & 23 & 7 & 863 & 16 & $0.743 \pm 0.081$ & $0.0095 \pm 0.0051$ \\
\hline Quebrada de Jere (haplogroup 1) & 11 & 1 & 862 & 0 & $0.000 \pm 0.000$ & $0.0000 \pm 0.0000$ \\
\hline Quebrada de Jere (haplogroup 2) & 12 & 6 & 863 & 4 & $0.849 \pm 0.074$ & $0.0018 \pm 0.0013$ \\
\hline Peine & 9 & 1 & 862 & 0 & $0.000 \pm 0.000$ & $0.0000 \pm 0.0000$ \\
\hline Tilomonte & 17 & 3 & 862 & 2 & $0.324 \pm 0.136$ & $0.0004 \pm 0.0005$ \\
\hline
\end{tabular}

diate populations might link those two groups. The present study suggests that this is not the case, and that there is a well-defined limit between these two intra-specific lineages, located between $21^{\circ} 05^{\prime} \mathrm{S}$ and $21^{\circ} 15^{\prime} \mathrm{S}$, although the available information cannot exclude a possible zone of secondary contact.

The two main lineages differ in their degree of phylogeographic structure (fig. 2; table 2$)$. Whereas the northern lineage $\left(17^{\circ} 44^{\prime} \mathrm{S}\right.$ - 
$21^{\circ} 04^{\prime} \mathrm{S}$ ) showed little structure and haplotypes with a wide geographic distribution, the southern lineage $\left(21^{\circ} 17^{\prime} \mathrm{S}-23^{\circ} 47^{\prime} \mathrm{S}\right)$ includes a very divergent group of haplotypes from the southeast of the Salar de Atacama (Quebrada de Jere, Peine and Tilomonte, $23^{\circ} 11^{\prime} \mathrm{S}-23^{\circ} 47^{\prime} \mathrm{S}$ ), which would account for its greater degree of structure (fig. 2). This corroborates the genetic pattern observed by Méndez et al. (2004) with RAPD markers, where one of the populations of the southeast of the Salar de Atacama (Quebrada de Jere) appears separated in a UPGMA tree from some of the populations near the Loa River (Tatio, Chita and Vilama) included in this study. The concordance between the levels of divergence found using mitochondrial DNA sequences and nuclear RAPD markers for these populations and for the northern and southern lineages mentioned above suggests that the phylogeographic patterns found with the mitochondrial control region are a good approximation to the genetic differentiation of this species in this region of Chile.

The northern lineage is distributed in a northsouth series of small endorheic drainage systems (from Caquena to Alconcha; fig. 1) which are closed or drain towards the east in hydrographic systems of Bolivia (Niemeyer and Cereceda, 1984). A common point for all these systems is that they were connected to extensive paleolakes which were formed at the end of the Pleistocene and whose remains currently form the lakes or salt flats of Poopó, Coipasa and Uyuni in Bolivia (Placzek et al., 2006). However, additional data are needed to determine if the population expansion of the northern lineage, inferred from Fu's $F s$ test and the mismatch distribution (table 3), may be associated with the expansion of one of these paleolacustrine systems. On the other hand, part of the genetic differentiation observed within this group may be due to the more recent formation of some of the drainage systems it occupies (e.g., Chungará, Surire) due to volcanic activity (Ochsenius, 1974), which may have isolated some populations.
A singular aspect of the northern lineage is that it includes the only known populations of $R$. spinulosa that live below $1000 \mathrm{~m}$ (Azapa and Lluta). With respect to the geographic distribution of the haplotypes of the Azapa population, it is important to note that two of them were also found in Chusmisa, located more than $160 \mathrm{~km}$ to the southeast in the arheic drainage basin of Pampa del Tamarugal (fig. 1). A possible explanation for the genetic affinity of these two populations, which are in the western border of the distribution of the species (and were distinguished as a group by SAMOVA), is that they belong to an old colonization front which expanded to the west when the climate of this area was more humid. One possible mechanism to explain the presence of the species in these marginal localities, particularly Chumisa, is the infrequent events of water discharge towards the arheic drainages in the Atacama Desert (Nester et al., 2007). Aditionally, the peripheral populations of the extreme north may be the result of range expansions aided by the floods produced during ENSO events (Garreaud et al., 2003), facilitated by the exorheic nature of the rivers Lluta and San José de Azapa.

As mentioned above, the greater degree of phylogeographic structure of the southern lineage is due principally to the high degree of divergence of the haplogroup present to the east of the Salar de Atacama (Quebrada de Jere, Peine and Tilomonte; fig. 2). The other haplogroup is present in populations located in the drainage system of the Loa River (the largest river which traverses the Atacama Desert) and the area north and northeast of the Salar de Atacama. This haplogroup is in expansion according to Fu's Fs test and the mismatch distribution (table 3), which may explain its presence both in the highest parts of the drainage systems of Loa River and the Salar de Atacama (over $3000 \mathrm{~m}$ ) and in the lower altitude localities located in the western border (Loa River) and in the south of its distribution (north and east of the Salar de Atacama). A population expansion process supports the idea of a secondary contact 
to explain the presence of haplotypes of the two haplogroups of the southern lineage in the Quebrada de Jere locality (fig. 2). However, nuclear evidence is required to evaluate other explanations, for example recent translocation of individuals due to human activity.

According to the demographic analyses, the majority of the populations included in this study represent lineages that are expanding (table 3). Although it has been documented that the Altiplano zone of Chile has been in a period of drought since the late Holocene (e.g., Latorre et al., 2003; Valero-Garcés et al., 2003), several authors have described changes in precipitation patterns which have resulted in expansions and contractions of the plant formations since the end of the Pleistocene and during all the Holocene (Betancourt et al., 2000; Bobst et al., 2001; Latorre et al., 2003; Fritz et al., 2004; Latorre et al., 2006; Quade et al., 2008). Thus it is necessary to consider these climatic changes, which have produced expansions and contraction of the aquatic habitats of this species, to explain its presence in areas below $1000 \mathrm{~m}$ in the foothills of the drainage systems of Lluta, Azapa and Pampa del Tamarugal (fig. 1) and the existence of lineages not related phylogenetically in contiguous geographic zones.

The most relevant result of this study is the high genetic divergence found between the two lineages of $R$. spinulosa that inhabit in the Chilean Altiplano and adjacent areas. However, we do not know the extension of these lineages in the Altiplano areas of neighboring countries and the causes that originated this differentiation, especially considering the absence of current geographical barriers. The other studies performed in the same area at the species level have attributed speciation patterns to climatic and orogenic processes of the Pleistocene which may also have produced differentiation at the intraspecific level (Lüssen et al., 2003; Palma et al., 2005). Lüssen et al. (2003) found two lineages of Orestias (composed of various species) in the Chilean Altiplano, whose geographic limit is at about $19^{\circ} 30^{\prime} \mathrm{S}$. The limit es- tablished between the two main lineages of $R$. spinulosa does not coincide with the limit described for the species of Orestias, which suggests that the diversification of these two taxa was not produced by the same historical events. On the other hand, Palma et al. (2005) provided evidence in support of a peripatric speciation model for sigmodontine rodents of the Altiplano and Atacama Desert. This evidence may support a model of peripatric differentiation for some populations of $R$. spinulosa, particularly those of Quebrada de Jere, Peine and Tilomonte, which may be relict lineages that were isolated when the species had a wider distribution. The high level of nucleotide variation in these populations, compared to those from farther north (table 5), as well as their location in the southwest border of the known distribution range of the species in Chile supports this last interpretation.

Due to their low vagility and their phylopatry, amphibians tend to present highly genetically structured populations over short geographic distances; thus they may retain the signals of historical events that have generated their current distributions (Vences and Wake, 2007; Zeisset and Beebee, 2008). Thus phylogeographic studies in amphibians may provide valuable information on the events of the late Pleistocene and Holocene those have influenced biogeographic processes (Zeisset and Beebee, 2008). The phylogeographic patterns described in $R$. spinulosa, together with information about other taxa, will help to understand the patterns of differentiation of the taxa which inhabit this part of the Altiplano, one of the regions in the Southern Hemisphere in which phylogeographic studies are still scarce (Beheregaray, 2008).

Acknowledgements. The authors thank financial support provided by FONDECYT grant 1061256 and Proyecto Domeyko, Iniciativa Transversal 1, Universidad de Chile. SAG (Servicio Agrícola y Ganadero) supplied collecting permits (Resolution numbers 3085/2000, 2105/2004 and 13/2006). C. Correa thanks the Beca CONICYT for doctoral studies. 


\section{References}

Arroyo, M.T.K., Squeo, F., Armesto, J., Villagrán, C. (1988): Effects of aridity on plant diversity in the northern Chilean Andes: results of a natural experiment. Ann. Missouri Bot. Gard. 75: 55-78.

Bandelt, H.-J., Forster, P., Röhl, A. (1999): Median-joining networks for inferring intraspecific phylogenies. Mol. Biol. Evol. 16: 37-48.

Beheregaray, L.B. (2008): Twenty years of phylogeography: the state of the field and the challenges for the Southern Hemisphere. Mol. Ecol. 17: 3754-3774.

Betancourt, J.L., Latorre, C., Reach, J.A., Quade, J., Rylander, K.A. (2000): A 22 000-year record of monsoonal precipitation from northern Chile's Atacama Desert. Science 289: 1542-1546.

Bobst, A.L., Lowenstein, T.K., Jordan, T.E., Godfrey, L.V., Ku, T.-L., Luo, S. (2001): A 106 ka paleoclimate record from drill core of the Salar de Atacama, northern Chile. Palaeogeogr. Palaeoclimatol. Palaeoecol. 173: 21-42.

Cei, J.M. (1972): Bufo of South America. In: Evolution in the Genus Bufo, p. 82-92. Blair, W.F., Ed., University of Texas Press, Austin.

Dupanloup, I., Schneider, S., Excoffier, L. (2002): A simulated annealing approach to define the genetic structure of populations. Mol. Ecol. 11: 2571-2581.

Dyer, B.S. (2000): Systematic review and biogeography of the freshwater fishes of Chile. Est. Oceanol. (Chile) 19: 77-98.

Ezcurra, C. (2002): Phylogeny, morphology, and biogeography of Chuquiraga, an Andean-Patagonian genus of Asteraceae-Barnadesioideae. Bot. Rev. 68: 153-170.

Formas, J.R., Veloso, A., Ortiz, J.C. (2005): Sinopsis de los Telmatobius de Chile. Monogr. Herpetol. 7: 103-114.

Fritz, S.C., Baker, P.A., Lowenstein, T.K., Seltzer, G.O., Rigsby, C.A., Dwyer, G.S., Tapia, P.M., Arnold, K.K., $\mathrm{Ku}$, T.-L., Luo, S. (2004): Hydrologic variation during the last 170000 years in the southern hemisphere tropics of South America. Quat. Res. 61: 95-104.

Garreaud, R., Vuille, M., Clement, A.C. (2003): The climate of the Altiplano: observed current conditions and mechanisms of past changes. Palaeogeogr. Palaeoclimatol. Palaeoecol. 194: 5-22.

Goebel, A.M., Donnelly, J.M., Atz, M.E. (1999): PCR primers and amplification methods for $12 \mathrm{~S}$ ribosomal DNA, the control region, cytochrome oxidase I, and cytochrome $b$ in bufonids and others frogs, and an overview of PCR primers which have amplified DNA in amphibians successfully. Mol. Phylogenet. Evol. 11: 163-199.

Hall, T.A. (1999): BioEdit: a user-friendly biological sequence alignment editor and analysis program for Windows 95/98/NT. Nucl. Acids Symp. Ser. 41: 95-98.

Jowett, T. (1986): Preparation of nucleic acids. In: Drosophila: A Practical Approach, p. 275-286. Roberts, D.B., Ed., IRL Press, Oxford.

Koscinski, D., Handford, P., Tubaro, P.L., Sharp, S., Lougheed, S.C. (2008): Pleistocene climatic cycling and diversification of the Andean treefrog, Hypsiboas andinus. Mol. Ecol. 17: 2012-2025.
Latorre, C., Betancourt, J.L., Rylander, K.A., Quade, J., Matthei, O. (2003): A vegetation history from the arid prepuna of northern Chile $\left(22-23^{\circ} \mathrm{S}\right)$ over the last 13500 years. Palaeogeogr. Palaeoclimatol. Palaeoecol. 194: 223-246.

Latorre, C., Betancourt, J.L., Arroyo, M.T.K. (2006): Late Quaternary vegetation and climate history of a perennial river canyo in the Río Salado basin $\left(22^{\circ} \mathrm{S}\right)$ of Northen Chile. Quat. Res. 65: 450-466.

Lüssen, A., Falk, T.M., Villwock, W. (2003): Phylogenetic patterns in populations of Chilean species of the genus Orestias (Teleostei: Cyprinodontidae): results of mitochondrial DNA analysis. Mol. Phylogenet. Evol. 29: 151-160.

Méndez, M.A., Soto, E.R., Correa, C., Veloso, A., Vergara, E., Sallaberry, M., Iturra, P. (2004): Morphological and genetic differentiation among Chilean populations of Bufo spinulosus (Anura: Bufonidae). Rev. Chil. Hist. Nat. 77: 559-567.

Morrone, J.J. (2004): Panbiogeografía, componentes bióticos y zonas de transición. Rev. Bras. Entomol. 48: 149162.

National Research Council (1996): Guide for the Care and Use of Laboratory Animals. Institute for Laboratory Animal Resources. National Academy Press, Washington, DC.

Nester, P.L., Gayó, E., Latorre, C., Jordan, T.E., Blanco, N. (2007): Perennial stream discharge in the hyperarid Atacama Desert of northern Chile during the latest Pleistocene. PNAS 104: 19724-19729.

Niemeyer, H., Cereceda, P. (1984): Hidrografía de Chile. Colección de Geografía de Chile, Tomo VIII. Instituto Geográfico Militar, Chile.

Ochsenius, C. (1974): Relaciones paleobiogeográficas y paleoecológicas entre los ambientes lénticos de la Puna de Atacama y Altiplano boliviano, Trópico de Capricornio. Bol. Prehist. Chile 7-8: 99-138.

Palma, R.E., Rivera-Milla, E., Yates, T.L., Marquet, P.A., Meynard, A.P. (2002): Phylogenetic and biogeographic relationships of the mouse opossum Thylamys (Didelphimorphia, Didelphidae) in Southern South America. Mol. Phylogenet. Evol. 25: 245-253.

Palma, R.E., Marquet, P.A., Boric-Bargetto, D. (2005): Inter- and intraspecific phylogeography of small mammals in the Atacama Desert and adjacent areas of northern Chile. J. Biogeogr. 32: 1931-1941.

Placzek, C., Quade, J., Patchett, P.J. (2006): Geochronology and stratigraphy of late Pleistocene lake cycles on the southern Bolivian Altiplano: implications for causes of tropical climate change. Geol. Soc. Am. Bull. 118: 515532.

Quade, J., Rech, J.A., Betancourt, J.L., Latorre, C., Quade, B., Aasen Rylander, K., Fisher, T. (2008): Paleowetlands and regional climate change in the central Atacama Desert, northern Chile. Quaternary Research 69: 343360.

Rogers, A.R., Harpending, H. (1992): Population growth makes waves in the distribution of pairwise genetic differences. Mol. Biol. Evol. 9: 552-569. 
Rozas, J., Sánchez-DelBarrio, J.C., Messeguer, X., Rozas, R. (2003): DnaSP, DNA polymorphism analyses by the coalescent and other methods. Bioinformatics 19: 24962497.

Strecker, M.R., Alonso, R.N., Bookhagen, B., Carrapa, B., Hilley, G.E., Sobel, E.R., Trauth, M.H. (2007): Tectonics and climate of the southern central Andes. Annu. Rev. Earth Planet. Sci. 35: 747-787.

Tamura, K., Dudley, J., Nei, M., Kumar, S. (2007): MEGA4: Molecular Evolutionary Genetics Analysis (MEGA) software version 4.0. Mol. Biol. Evol. 24: 1596-1599.

Thompson, J.D., Gibson, T.J., Plewniak, F., Jeanmougin, F., Higgins, D.G. (1997): The ClustalX windows interface: flexible strategies for multiple sequence alignment aided by quality analysis tools. Nucl. Acids Res. 24: 48764882 .

Trumbull, R.B., Riller, U., Oncken, O., Scheuber, E., Munier, K., Hongn, F. (2006): The time-space distribution of Cenozoic volcanism in the south-central Andes: a new data compilation and some tectonic implications. In: The Andes - Active Subduction Orogeny, p. 29-43. Oncken, O., Chong, G., Franz, G., Giese, P., Götze, H.-J., Ramos, V.A., Strecker, M.R., Wigger, P., Eds, Springer, Berlin.

Valero-Garcés, B.L., Delgado-Huertas, A., Navas, A., Edwards, L., Schwalb, A., Ratto, N. (2003): Patterns of regional hydrological variability in central-southern Alti- plano $\left(18^{\circ}-26^{\circ} \mathrm{S}\right)$ lakes during the last 500 years. Palaeogeogr. Palaeoclimatol. Palaeoecol. 194: 319-338.

Veloso, A., Arroyo, M.K. (1982): Características del medio físico. In: El Ambiente Natural y las Poblaciones Humanas de los Andes del Norte Grande de Chile (Arica, Lat. $18^{\circ} 28^{\prime}$ S), vol. I, p. 5-12. Veloso, A., Bustos, E., Eds, ROSTLAC, Montevideo.

Veloso, A., Sallaberry, M., Navarro, J., Iturra, P., Valencia, J., Penna, M., Díaz, N. (1982): Contribución al conocimiento de la herpetofauna del extremo norte de Chile. In: La Vegetación y Vertebrados Ectotérmicos del Transecto Arica-Lago Chungará, vol. I, p. 135-268. Veloso, A., Bustos, E., Eds, ROSTLAC, Montevideo.

Vences, M., Wake, D.B. (2007): Speciation, species boundaries and phylogeography of amphibians. In: Amphibian Biology, Systematics, vol. 6, p. 2613-2669. Heatwole, H.H., Tyler, M., Eds, Surrey Beatty \& Sons, Chipping Norton, Australia.

Zeisset, I., Beebee, T.J.C. (2008): Amphibian phylogeography: a model for understanding historical aspects of species distributions. Heredity 101: 109-119.

Received: January 28, 2009. Accepted: July 29, 2009. 